\title{
Upaya Meningkatkan Prestasi Belajar Pendidikan Agama Islam Dan Budi Pekerti Melalui Pemberian Tugas Berbasis Portofolio Pada Siswa Kelas VIII.11 SMPN 1 Praya Tahun Pelajaran 2018/2019
}

\author{
Lukman \\ Guru PAI SMP Negeri 1 Praya Lombok Tengah
}

\begin{abstract}
Abstrak. Penelitian ini bertujuan untuk: 1) mengetahui pelaksanaan pemberian tugas berbasis portofolio untuk meningkatkan prestasi belajar PAI pada siswa kelas VIII.11 SMPN 1 Praya, 2) meningkatkan prestasi belajar PAI pada siswa kelas VIII.11 SMPN 1 Praya melalui pemberian tugas berbasis portofolio. Penelitian ini merupakan Penelitian Tindakan Kelas (PTK), terdiri dari tiga siklus yang masing-masing siklus terdiri atas perencnaan, pelaksanaan, observasi, analisis dan refleksi. Subjek penelitian ini adalah siswa kelas VIII.11 SMPN 1 Praya yang mempunyai prestasi belajar rendah pada mata pelajaran PAI disebabkan kurangnya fariasi metode pemberlajaran yang selama ini berlangsung. Peneliti kemudian menggunakan strategi pembelajaran dengan pemberian tugaVIII.11 SMPN 1 Praya berbasis portofolio untuk meningkatkan prestasi belajar PAI pada siswa ke. Tehnik pengumpulan data dalam penelitian ini adalah menggunakan metode tes untuk mengetahui tingkat pemahaman siswa terhadap konsep pendidikan agama Islam, metode observasi untuk mengmati proses pembelajaran pendidikan agama Islam melalui pemberian tugas berbasis portofolio (aktifita guru, patisipasi siswa), dan metode dokumentasi untuk mengetahui nam siswa, jumlah siswa dan nilai pendidikan agama Islam baik sebelum / sesudah diberi pembelajaran dengan pemberian tugas berbasis portofolio. Setelah dilaksanakan tindakan melalui pemberian tugas berbasis portofolio, prestasi belajar PAI siswa kelas VIII.11 SMPN 1 Praya meningkat. Hal ini ditunjukkan dengan meningkatnya rerata penilaian tes akhir siswa pada tiap siklusnya, yaitu : siklus $\mathrm{I}=6,70$, siklus II $=7,10$ dan siklus III $=7,70$. Dari hasil penelitian tersebut, diharapkan strategi pembelajaran dengan pemberian tugas berbasis portofolio untuk meningkatkan prestasi belajar siswa dapat diterapkan oleh guru mata pelajaran PAI pada khususnya dan mata pelajaran lain pada umumnya.
\end{abstract}

Kata kunci; PAI, Pemberian Tugas Berbasisi Portofolio

\section{PENDAHULUAN}

Dalam rangka mewujudkan manusia yang beriman dan bertaqwa kepada Tuhan Yang Maha Esa, berbudi pekerti luhur dan memiliki pengetahuan dan keterampilan yang cukup sebagaimana yang dikehendaki oleh tujuan Pendidikan Nasional, maka hendaknya pendidikan tidak hanya sebuah transfer of knowledge tetapi juga transfer of value. Pendidikan harus mampu mengantarkan manusia mencapai kompetensi intelektualitasnya sekaligus mengemban spiritualitas sebagai potensi kemanusiaannya. Diri manusia adalah entitas yang kompleks dengan potensi akal dan rasa yang harus dikembangkan secara berimbang. Pendidikan yang hanya menekankan pada pentingnya akal dan hanya dilakukan sebagai transfer pengetahuan dan teknologi saja, hanya akan mencetak manusia dengan mental robot. Untuk itu, pendidikan pun harus juga memberi kesadaran akan nilainilai dalam kehidupan manusia, sehingga perilaku dan sikap hidup manusia tidak hanya didasari pertimbangan rasio: benar salah, untung rugi, tetapi juga pertimbangan etis: baik buruk yang mencerminkan kualitas kemanusiaan.

Dengan diberlakukannya otonomi daerah, maka sekolah juga perlu penyesuaian dari manajemen paradigma lama menuju pendidikan paradigma baru yang lebih bernuansa otonomi dan lebih demokratis. Manajemen Berbasis Sekolah 
(MBS) merupakan modal manajemen yang memberikan otonomi lebih besar dari pada sekolah dan mendorong pengambilan keputusan bersama atau partisipasi dari semua warga sekolah dalam meningkatkan mutu pendidikan berdasarkan kebijakan Nasional. Tujuan utama MBS diantaranya adalah peningkatan mutu diperoleh melalui partisipasi orang tua, kelenturan pengelolaan sekolah, peningkatan profesionalisme guru, adanya hadiah hukuman sebagai kontrol, serta hal lain yang dapat menumbuhkembangkan suasana yang kondusif.

Berbagai upaya telah dilakukan untuk meningkatkan mutu Pendidikan Nasional, khususnya pendidikan dasar dan menengah pada setiap jenjang dan satuan pendidikan. Beberapa upaya tersebut antara lain melalui berbagai pelatihan dan peningkatan kompetensi guru, pengadaan buku dan alat pelajaran, perbaikan sarana dan prasarana pendidikan dan peningkatan mutu manajemen sekolah.

Dalam lingkup kelas maka guru mempunyai peran yang strategis untuk meningkatkan kualitas pembelajaran. Guru merupakan personil sekolah yang memiliki kesempatan bertatap muka lebih banyak dengan siswanya. Dengan demikian peran dan tanggung jawab guru adalah menguasai dan mengembangkan materi pelajaran, merencanakan, mempersiapkan pelajaran, mengontrol dan mengevaluasi kegiatan siswa.

Kenyataan di lapangan banyak guru yang memberi pelajaran untuk keperluan ujian yang segera akan dilupakan oleh anak-anak. Akan tetapi bukan itu hasil belajar yang diinginkan. Yang diharapkan ialah agar anak-anak memahami pelajaran secara mendalam sehingga ia lama mengingatnya serta dapat menggunakannya dalam hidupnya.

Seorang guru bukan hanya sekedar pemberi ilmu pengetahuan kepada muridmuridnya. Akan tetapi, dia seorang tenaga profesional yang dapat menjadikan muridmuridnya mampu merencanakan, menganalisis dan menyimpulkan masalah yang dihadapi.
Permasalahan yang sering muncul dalam pembelajaran PAI adalah masih rendahnya pemahaman siswa terhadap konsep PAI yang diajarkan guru. Buktibukti penilaian ulangan harian dan ulangan umum menunjukkan bahwa prestasi belajar PAI belum sesuai dengan standar ketuntasan minimal.

Oleh karena itu, untuk meningkatkan mutu pendidikan diperlukan perubahan pola pikir yang digunakan sebagai landasan pelaksanaan kurikulum masa lalu, proses belajar mengajar terfokus pada siswa, akibatnya KBM (Kegiatan Belajar Mengajar) lebih menekankan pada pengajaran dari pada pembelajaran. Untuk itu diperlukan strategi pembelajaran.

Salah satu strategi pembelajaran yang memusatkan proses pembelajaran pada siswa adalah metode pembelajaran dan penilaian portofolio. Model pembelajaran ini berpusat pada siswa, karena dapat mendorong kompetensi, tanggungjawab dan partisipasi siswa belajar menilai dan mempengaruhi kebijakan umum, memberanikan diri untuk berperan serta dalam kegiatan antar siswa, antar sekolah dan antar anggota masyarakat.

PAI. Dalam portofolio PAI ini siswa dibina agar memiliki kecakapan untuk memecahkan masalah-masalah yang terjadi di masyarakat yang erat kaitannya dengan materi pokok PAI, misalnya masalah keimanan dan ketauhidan, pembelajaran diharapkan dapat menciptakan akhlak peserta didik menjadi muslim yang beriman dan bertaqwa. Sesuai dengan pendapat Budimansyah bahwa portofolio sebenarnya dapat diartikan sebagai wujud benda fisik, sebagai suatu proses sosial pedagogis, maupun sebagai objective, maka peneliti membatasi penelitian ini pada pengertian portofolio sebagai wujud benda fisik, yaitu tugas portofolio. Dengan memanfaatkan lingkungan sekitar sebagai sumber belajar, maka dengan diberikannya tugas berbasis portofolio diharapkan dapat meningkatkan prestasi belajar siswa sehingga tujuan PAI dapat terwujud.

Berdasarkan uraian latar belakang permasalahan tersebut, maka sebagai upaya 
untuk meningkatkan pemahaman siswa terhadap PAI, peneliti kemudian akan melaksanakan penelitian Tindakan Kelas dengan judul "Upaya Meningkatkan Prestasi Belajar PAI Melalui Pemberian Tugas Berbasis Portofolio (Studi Tindakan Kelas Pada Siswa Kelas VIII.11 SMPN 1 Praya Tahun Pelajaran 2018/2019

\section{Perumusan Masalah}

Rumusan masalah dalam penelitian ini adalah " Bagaimanak Meningkatkan Prestasi Belajar PAI Melalui Pemberian Tugas Berbasis Portofolio (Studi Tindakan Kelas Pada Siswa Kelas VIII.11 SMPN 1 Praya Tahun Pelajaran 2018/2019?

\section{Tujuan Penelitian}

Tujuan Penelitian ini adalah untuk Meningkatkan Prestasi Belajar PAI Melalui Pemberian Tugas Berbasis Portofolio (Studi Tindakan Kelas Pada Siswa Kelas VIII.11 SMPN 1 Praya Tahun Pelajaran 2018/2019 Manfaat Penelitian

Penelitian ini dipandang sangat potensial untuk memperbaiki kualitas pembelajaran PAI dengan sasaran meningkatnya prestasi belajar PAI dan diharapkan dapat memberikan sumbangan yang positif dalam rangka perbaikan pembelajaran khususnya pada sekolah tempat penelitian (SMPN 1 Praya)

\section{Landasan Teori dan Kajian Pustaka Prestasi Belajar PAI}

Pengertian prestasi menurut kamus adalah hasil yang telah dicapai (dari yang telah dilakukan, dikerjakan, dan sebagainya). Lebih lanjut Arno F. Witting dalam bukunya Psychology of Learning mendefinisikan prestasi sebagai berikut : "Achievement refers to the measurement of some behavior at a given moment; it is assumed that

achievement reflect past learning".

(Prestasi merujuk pada pengukuran beberapa tingkah laku pada waktu yang ditentukan yang dianggap sebagai pencerminan dari pembelajaran yang telah lalu).

Adapun belajar adalah suatu proses usaha yang dilakukan individu untuk memperoleh suatu perubahan perilaku yang baru yang secara keseluruhan sebagai hasil pengalaman individu itu sendiri dalam interaksi dengan lingkungan.

Menurut Ngalim Purwanto, belajar merupakan suatu perubahan dalam tingkah laku, dimana perubahan itu dapat mengarah kepada tingkah laku. Tingkah laku yang mengalami perubahan karena belajar menyangkut berbagai aspek kepribadian, baik fisik maupun psikis. Seperti : perubahan dalam pengertian, pemecahan suatu masalah / berpikir, ketrampilan, kecakapan, kebiasaan, ataupun sikap.

Belajar juga dapat diartikan sebagai proses transfer yang ditandai oleh adanya perubahan pengetahuan, tingkah laku dan kemampuan seseorang yang relatif tetap sebagai hasil dari latihan dan pengalaman yang terjadi melalui aktifitas mental yang bersifat aktif, konstruktif, komulatif dan berorientasi pada tujuan.

Dari beberapa definisi di atas, dapat dipahami bahwa prestasi belajar adalah ukuran atau hasil yang dicapai seseorang setelah mengikuti proses belajar berupa perubahan tingkah laku secara keseluruhan sebagai hasil pengalaman individu itu sendiri dalam interaksi dengan lingkungannya. Sedangkan pendidikan agama Islam-lebih dipahami sebagai upaya atau cara mendidik ajaran agama Islam.

Pendidikan agama Islam menurut Abdul Madjid dan Dian Andayani adalah usaha sadar yang dilakukan oleh pendidik dalam rangka mempersiapkan peserta didik untuk meyakini, memahami dan mengamalkan ajaran agama Islam melalui bimbingan, pengajaran atau pelatihan yang telah ditentukan untuk mencapai tujuan yang harus ditetapkan.

Pendidikan agama Islam menurut Sutrisno Muslim adalah upaya sadar dan terencana dalam menyiapkan peserta didik untuk mengenal, memahami, menghayati hingga mengimani, bertaqwa dan berakhlak mulia dalam mengamalkan ajaran Islam dari sumber utamanya kitab suci al-Qur'an dan hadits, melalui kegiatan bimbingan, pengajaran, latihan, serta penggunaan pengalaman.

Faktor yang Mempengaruhi Prestasi Belajar Prestasi belajar yang dicapai 
seseorang merupakan hasil interaksi berbagai faktor yang mempengaruhinya baik dari dalam diri (faktor internal) maupun dari luar diri (faktor eksternal) individu. Pengenalan terhadap faktor-faktor yang mempengaruhi prestasi belajar penting sekali artinya dalam rangka membantu murid dalam mencapai prestasi belajar yang sebaik-baiknya.Yang tergolong faktor internal adalah : (1) Inteligensi, (2) Perhatian, (3) Bakat, (4) Motivasi

Selain faktor internal prestasi belajar juga dipengaruhi oleh faktor eksternal, adalah sebagai berikut : (a) Faktor keluarga, (b) Faktor sekolah, (b) Faktor masyarakat

\section{Tujuan Pendidikan Agama Islam}

Pendidikan Agama Islam di sekolah/madrasah bertujuan untuk menumbuhkan dan meningkatkan keimanan melalui pemberian dan pemupukan pengetahuan, pengetahuan, penghayatan, pengamalan, serta pengalaman peserta didik tentang agama Islam sehingga menjadi manusia muslim yang terus berkembang dalam hal keimanan, ketakwaannya, berbangsa dan bernegara, serta untuk dapat melanjutkan pada jenjang pendidikan yang lebih tinggi.

\section{Pengertian Portofolio}

Portofolio berasal dari bahasa Inggris "Portfolio" yang artinya dokumen atau surat-surat. Dapat juga diartikan sebagai kumpulan kertas- kertas berharga dari suatu pekerjaan tertentu.

Secara umum portofolio merupakan hasil karya siswa yang didokumentasikan secara baik dan teratur. Portofolio dapat berbentuk tugas- tugas yang dikerjakan siswa, laporan kegiatan siswa, dan karangan jurnal yang dibuat siswa.

Dalam area pendidikan, portofolio tidak hanya digunakan di sekolah, tetapi juga di lembaga pendidikan guru. Corak portofolio adalah ditentukan oleh tujuan dibuatnya portofolio. Tujuan portofolio akan mempengaruhi pertimbangan rancangan (desain) isi dan seleksi. Dalam penelitian ini difokuskan pada portofolio yang disusun untuk tujuan penilaian prestasi belajar siswa. Baik secara kualitatif (proses) maupun kuantitatif (angka) portofolio telah menjadi suatu alat penilaian jika bertujuan : (1) mendapatkan informasi tentang pertumbuhan atau kemajuan belajar siswa dan (2) mendapatkan data kemajuan belajar siswa yang dapat diproses menjadi nilai raport atau deskripsi prosentase kompetensi atau kemampuan siswa pada mapel tertentu.

\section{Teknik Penilaian Portofolio}

Penilaian dalam bahsa Inggris sering disebut assessment yang berarti penaksiran atau menaksir. Dalam bidang pendidikan assessment sering dikaitkan dengan pencapaian kurikulum, dan digunakan untuk mengumpulkan informasi berkenaan dengan proses pembelajaran dan hasilmnnya. Adapun maksud dari assessment adalah :

\section{Melacak kemajuan siswa (keeping track).}

Melacak ketercapaian pengetahuan

(checking up).

Mendeteksi kesalahan (finding out).

Menyimpulkan (summing up).

Assessment portofolio adalah penilaian terhadap kumpulan berkas sebagai bukti fisik setiap aktifitas siswa bisa berupa dokumen, hasil tes, tugas-tugas, catatan tentang sikap-minat, keterampilan dan kompetensi siswa.

Penilaian portofolio oleh guru didasarkan pada beberapa aspek penilaian dengan memperhatikan jenis tugas dengan diberikan aspek-aspek tersebut adalah : (1) Aspek pemahaman, seberapa baik tingkat pemahaman siswa terhadap soal-soal yang dikerjakan; (2) Aspek argumentasi, seberapa baik yang diberikan siswa dalam menjawab persoalan-persoalan di dalam lembar kerja siswa tersebut; dan (3) Aspek kejelasan, tersusun dengan baik, tertulis dengan baik, mudah dipahami.

\section{Metode Penelitian}

\section{Rancangan penelitian}

PTK merupakan suatu proses yang dilakukan seorang guru untuk mengetahui dan mencari pemecahan masalah terhadap kondisi kelasnya. Penelitian tindakan kelas ini dilaksanakan dalam 2 siklus. Setiap siklus terdiri atas empat tahap, yakni perencanaan, tindakan, observasi dan refleksi."Penelitian ini direncanakan dalam beberapa siklus.. Masing-masing siklus 
terdiri dari empat tahapan kegiatan yaitu perencanaan tindakan, pelaksanaan tindakan, observasi dan evaluasi, serta refleksi.( arikunto ;2013; 137) Adapun model dan penjelasan untuk masing-masing tahap adalah

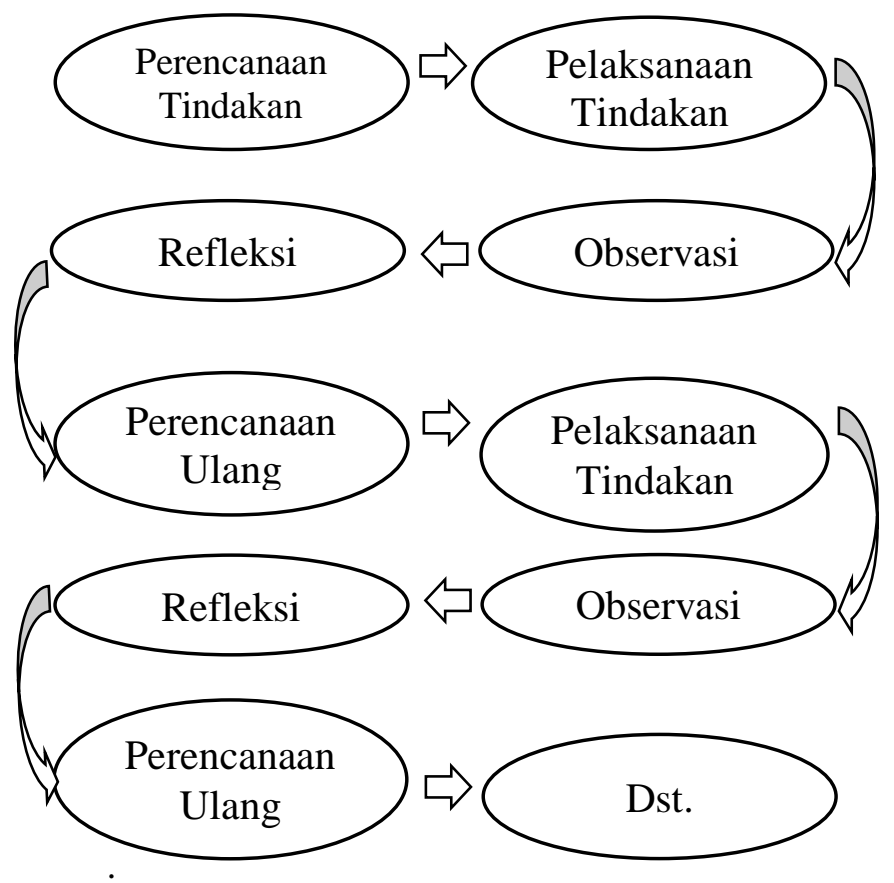

Subyek Penelitian

Subyek penelitian adalah siswa kelas VIII.II SMPN 1 Praya dengan kemampuan yang beragam ada siswa yang cepat menyerap pelajaran . ada yang sedang . dan ada yang lambat.

\section{Waktu penelitian}

Waktu yang digunakan untuk penelitian ini adalah semester II mulai bulan Februari sampai bulan Mei 2018 tahun pelajaran 2018 / 2019.

Data dan Teknik Pengumpulan Data

\section{Jenis Data}

Data Kuantitatif Data kualitatif diwujudkan dengan hasil prestasi belajar siswa melalui tes tertulis pada setiap akhir siklus.

Teknik Pengumpulan Data

Dalam penelitian ini menggunakan teknik.Tes dalam penelitian digunakan untuk mengukur hasil belajar siswa setelah mengikuti pembelajaran mata pelajaran PAI dengan menggunakan media tongkat berjalan. Tes dilakukan dua kali dalam bentuk pre test (untuk mengetahui kemampuan awal siswa) dan post test (untuk mengetahui kemampuan siswa setelah mengikuti pembelajaran).

Teknik Analisis Data:

Data Kuantitatif

Data kuantitatif berupa hasil belajar kognitif, dianalisis dengan menggunakan teknik analisis deskriptif dengan menentukan presentasi ketuntasan belajar dan mean (rerata) kelas. Rumus untuk menghitung persentase ketuntasan belajar adalah sebagai berikut

$$
P=\frac{\sum \text { Siswa yang tuntas }}{\sum \text { Siswa } \quad \text { (zaenal akib, 2010; 41) }}
$$

(a) Data nilai rata-rata dianalisis dengan rumus:

$$
x=\frac{\sum X}{\sum N}
$$

Keterangan :

$\mathrm{x}=$ nilai rata-rata

$\sum \mathrm{X}=$ jumlah semua nilai siswa

$\sum \mathrm{N}=$ jumlah siswa

(Zainal Aqib, 2009: 204)

\section{Hasil Penelitian dan Pembahasan Hasil Penelitian}

Penelitian tindakan kelas ini tersusun dalam suatu siklus dan setiap siklus terdiri dari beberapa tahapan, yaitu perencanaan, pelaksanaan tindakan, observasi, analisis dan refleksi. Pembelajaran PAI dengan strategi pemberian tugas portofolio pada siswa sekolah menengah pertama telah berhasil peneliti terapkan dalam bentuk tindakan kelas melalui tiga siklus. Siklus 1 peneliti laksanakan pada tanggal 23 April 2018 dengan materi sejarah pertumbuhan ilmu pengetahuan dalam Islam. Siklus II dilaksanakan tanggal 30 April 2018, dengan materi perilaku tercela (dendam dan munafik). Sedangkan siklus III peneliti laksanakan pada tanggal 7 Mei 2018, dengan materi binatang halal dan haram.

Paparan pembelajaran pada masingmasing siklus dalam penelitian ini dilakukan melaui tahap perencanaan, pelaksanaan pembelajaran, pengamatan, analisa dan refleksi.

Pelaksanaan Siklus I

Siklus I mulai dilaksanakan pada hari Rabu, tanggal 23 April 2018. Fokus pembelajaran adalah mata pelajaran PAI dengan materi Sejarah Pertumbuhan Ilmu Pengetahuan dalam Islam. Pembelajaran sebagian besar dilakukan dengan metode resitasi (penugasan kelas) dan diskusi kelas, selesai dalam waktu ( 2 x 40 menit). Pelaksanaan Siklus II 
Siklus II dilaksanakan pada hari Rabu, tanggal 30 April 2018. Fokus pembelajaran pada materi Perilaku Tercela (dendam dan munafik). Pembelajaran dilakukan dengan metode diskusi dilanjutkan dengan tugas portofolio dan evaluasi selesai dalam waktu ( 2 x 40$)$ Pelaksanaan siklus II sama dengan pelaksanaan siklus I, yaitu diawali dengan proses perencanaan, kemudian dilanjutkan dengan proses pelaksanaan pembelajaran, proses pengamatan dan proses analisis dan refleksi..

Dengan memperhatikan hasil analisis dan refleksi pada siklus II, peneliti kemudian merencanakan pembelajaran yang sama pada siklus III.

Pelaksanaan Siklus III

Siklus III dilaksanakan pada hari Rabu, 7 Mei 2018. Fokus pembelajaran pada materi PAI binatang halal dan haram. Pembelajaran dilakukan dengan metode diskusi dilanjutkan bimbingan pemberian tugas portofolio dan evaluasi. Pelaksanaan siklus tiga merupakan pengulangan pembelajaran pada siklus I dan siklus II. Pembelajaran diawali dengan proses perencanaan, kemudian dilanjutkan dengan proses pelaksanaan pembelajaran, proses pengamatan, dan proses analisis serta refleksi.

Rerata Penilaian Tugas Portofolio

\begin{tabular}{|c|c|c|}
\hline $\begin{array}{c}\text { Rerata } \\
\text { siklus I }\end{array}$ & $\begin{array}{c}\text { Rerata } \\
\text { siklus II }\end{array}$ & $\begin{array}{c}\text { Rerata } \\
\text { siklus III }\end{array}$ \\
\hline 6,54 & 7,40 & 7,74 \\
\hline
\end{tabular}

Berdasarkan tabel 7 tersebut, maka dapat dilihat bahwa terjadi peningkatan hasil pengerjaan tugas portofolio di setiap siklusnya. Pada siklus I, rerata penilaian tugas portofolio I hanya 6,54. kemudian di siklus II , rerata penilaian meningkat menjadi 7,40. sedangkan pada siklus III, terjadi lagi kenaikan rerata penilaian tugas portofolio III sebesar 7,74. terjadinya kenaikan rerata penilaian tugas portofolio tiap siklus pada penelitian ini menunjukkan efektifitas pembelajaran PAI dengan metode tugas portofolio.

Hasil rata-rata penilaian prestasi belajar

Untuk mengetahui kemampuan siswa dalam mengetahui materi PAI yang telah diajarkan melalui metode tugas portofolio, maka peneliti mengadakan evaluasi sebagai bentuk penilaian prestasi belajar. Evaluasi dilaksanakan pada akhir pembelajaran di tiap siklusnya. Dengan demikian, terdapat tiga kali tes akhir dalam penelitian ini. Hasil belajar pada setiap siklusnya dapat dilihat pada lampiran 20. Rerata hasil belajar PAI siswa sesudah menerapkan metode tugas portofolio dapat dilihat pada tabel berikut. Rerata Penilaian Tes Akhir Pembelajaran PAI Dengan Metode Tugas Portofolio

\begin{tabular}{|c|c|c|}
\hline $\begin{array}{c}\text { Rerata } \\
\text { siklus I }\end{array}$ & $\begin{array}{c}\text { Rerata } \\
\text { siklus II }\end{array}$ & $\begin{array}{c}\text { Rerata } \\
\text { siklus III }\end{array}$ \\
\hline 6,70 & 7,10 & 7,70 \\
\hline
\end{tabular}

Berdasarkan tabel tersebut diatas, maka dapat diketahui bahwa indikator kinerja untuk penilaian hasil tes akhir siswa sudah tercapai pada siklus III. Setelah diterapkan metode tugas portofolio dalam pembelajaran PAI, maka terjadi peningkatan rerata penilaian tes akhir siswa, rerata penilaian siklus I sebesar 6,70 dan meningkat menjadi 7,10 pada siklus II, sedangkan pada siklus III rerata penilaian meningkat lagi menjadi 7,70.

\section{Pembahasan}

Analisis hasil penelitian dalam hal ini berdasarkan hasil pengamatan dan refleksi kegiatan masing-masing siklus. Sebelum melaksanakan pembelajaran PAI dengan pemberian tugas portofolio, aktivitas siswa dalam belajar kurang. Hal tersebut tampak pada banyaknya siswa yang kurang merespon penjelasan guru, motivasi untuk belajar masih rendah. Banyak siswa yang bersikap acuh tak acuh terhadap penjelasan guru.

Pada saat pembelajaran PAI dengan memberikan tugas portofolio ternyata aktivitas siswa dalam pembelajaran meningkat. Aktifitas siswa pada pertemuan pertama masih belum nampak. Hal ini dapat dipahami, karena metode pemberian tugas portofolio ini merupakan model 
pembelajaran yang baru, karena siswa sebelumnya mendapatkan materi pelajaran secara verbalistik oleh guru. Sebagian siswa belum memahami proses pembelajaran dengan metode tersebut. pada pertemuan selanjutnya yaitu penemuan kedua dan pada pertemuan ketiga, situasi pembelajaran menjadi berubah konsentrasi belajar siswa menjadi tinggi. Hal tersebut dibuktikan dengan banyaknya siswa yang aktif bertanya jawab dalam diskusi.

Berdasarkan hasil pembelajaran yang sudah dicapai pada siklus I, siklus II, dan siklus III, maka diperoleh model pembelajaran PAI dengan pemberian tugas portofolio sebagai berikut: (1) Pembelajaran PAI dengan strategi pemberian tugas portofolio, dapat dilakukan variasi pembelajaran. (2) pemberian tugas portofolio lebih efektif jika disusun dengan tujuan untuk meningkatkan interaksi siswa. (3) pengerjaan tugas portofolio dilakukan secara individu, sehingga guru dapat melakukan penilaian secara objektif. Dengan demikian, nilai akhir yang dicapai siswa merupakan serangkaian nilai pada kriteria penilaian.

Beberapa kelebihan dari penerapan metode pemberian tugas portofolio ini dapat di jelaskan sebagai berikut: (1) Guru dapat memfungsikan diri sebagai fasilitator dan motivator yang baik dalam pembelajaran, (2) Meningkatkan interaksi siswa dan lebih mengaktifkan siswa dalam pembelajaran, (3)Memberi kesempatan siswa seluasluasnya untuk mengembangkan ide dan penjelasan mereka terhadap suatu masalah, dan, (4) Dapat meningkatkan pemahaman siswa terhadap materi yang diajarkan guru.

Sebelum menggunakan metode pemberian tugas portofolio dalam pembelajaran PAI rerata hasil belajar siswa hanya 6,50 setelah menerapkan metode pemberian tugas portofolio dalam pembelajaran PAI, nilai hasil belajar siswa meningkat. Hal tersebut dibuktikan pada siklus I, rerata nilai belajar siswa sebesar 6,70, siklus II sebesar 7,10 dan siklus III sebesar 7,70. Terjadinya peningkatan rerata nilai ini, dapat dijelaskan karena sebelum menerapkan metode pemberian tugas portofolio, guru lebih dominan menggunakan metode klasikal yaitu ceramah atau tanya jawab saja. Ternyata, pembelajaran yang monoton tersebut menyebabkan motivasi belajar menjadi rendah dan keaktifan siswa dalam pembelajaran belum tampak. Setelah menerapkan metode pemberian tugas portofolio dalam pembelajaran PAI, keaktifan siswa tampak. Dengan melibatkan siswa secara langsung dalam pembelajaran, misalnya pada saat melakukan diskusi dalam mempresentasikan materi, keberanian siswa tumbuh.

Secara umum, respon siswa terhadap pembelajaran PAI dengan metode pemberian tugas portofolio adalah positif. Respon positif tersebut ditunjukkan oleh pernyataan-pernyataan siswa dalam pembelajaran PAI dengan metode pemberian tugas portofolio merupakan model pembelajaran sebagai variasi dalam pembelajaran. Siswa mengharapkan agar metode ini dapat diterapkan pada mata pelajaran yang lain, tidak hanya sebatas pada pelajaran PAI.

Respon guru dan observer terhadap pembelajaran PAI menggunakan metode pemberian tugas portofolio secara umum juga baik. Mereka memberikan pernyataan bahwa pembelajaran PAI dengan metode pemberian tugas portofolio cukup efektif. Guru dapat memfungsikan dirinya sebagai fasilitator dan motivator yang baik dalam pembelajaran.

Berdasarkan uraian tersebut diatas, maka dapat dikatakan bahwa dengan menerapkan metode pemberian tugas portofolio pada pembelajaran PAI dapat meningkatkan prestasi belajar siswa. Secara khusus bahwa penerapan metode pemberian tugas portofolio dalam pembelajaran PAI telah dapat meningkatkan pemahaman terhadap materi PAI yang diajarkan pada kelas VIII.11 tahun 2018/2019.

\section{Kesimpulan}

Berdasarkan hasil penelitian tindakan kelas pada pembelajaran PAI dengan strategi pemberian tugas portofolio yang telah peneliti laksanakan di kelas VIII.11 SMPN 1 Praya beberapa hal 
sebagai berikut: (1) Pembelajaran PAI melalui metode pemberian tugas portofolio dilaksanakan di kelas. Siswa mengerjakan tugas portofolio tersebut setelah selesai melakukan diskusi kelas, selanjutnya diadakan evaluasi akhir pembelajaran, (2) Pembelajaran PAI melalui pemberian tugas portofolio dapat meningkatkan prestasi belajar siswa kelas VIII.11 SMPN 1 Praya. Hal ini ditunjukkan dengan meningkatnya rerata penilaian tes akhir siswa pada tiap siklusnya, yaitu : siklus $\mathrm{I}=6,54$, siklus II $=$ 7,40, dan siklus III = 7,74.

\section{DAFTAR PUSTAKA}

Aqib, Zaenal, Penelitian Tindakan Kelas, Bandung: Yrama Widya, 2006.

Azizy, A. Qodri, Pendidikan Agama Untuk Membangun Etika Sosial, Semarang: Aneka Ilmu, 2007.

Budimansyah, Dasim, Model Pembelajaran dan Penilaian Berbasis Portofolio,

Bandung: PT. Grasindo, 2002.

, Model Pembelajaran Portofolio PAI, Bandung: Genesindo, 2003. Darajat, Zakiah, dkk., Ilmu Pendidikan Islam, Jakarta: Bumi Aksara, 1996.

Debdiknas, Model Silabus dan Rencana Pelaksanaan Pembelajaran, t.th.

Departemen Pendidikan Direktorat Jendral Pendidikan Dasar dan Menengah,

Penelitian Tindakan Kelas, Direktorat Tenaga Kependidikan, 2003.

Fajar, Arnie, Portofolio Dalam Pelajaran IPS, Bandung : PT Remaja Rosdakarya, 2004.

http://Sutris 02.Wordpress.com http://www.transdigit.com/article/port ofolio dan paradigma baru.htm

Jurnal Studi Islam, Program Pasca Sarjana, IAIN Walisongo Semarang, 2004.

Majid, Abdul dan Dian Andayani, Pendidikan Agama Islam Berbasis Kompetensi Konsep dan Implementasi Kurikulum 2004, Bandung : Remaja Rosdakarya, 2004.

Majid, Abdul, Perencanaan Pembelajaran, Bandung: Remaja Rosdakarya, 2006 Margono, S., Metode Penelitian Pendidikan, Jakarta: Rinneka Cipta,
2005

Muhaimin, dkk., Paradigma Pendidikan Islam, Upaya Mengefektifkan Pendidikan Agama Islam di Sekolah, Bandung: PT. Remaja Rosdakarya, 2002.

Mulyasa, E., Manajemen Berbasis Sekolah, Bandung: PT. Remaja Rosdakarya, 2004.

Musell, J. \& Nasution, Mengajar dengan Sukses, Jakarta: Bumi Aksara, 1995. Nurdin, Syafrudin dan $M$. Basyiruddin Usman, Guru Profesional \& Implementasi

Kurikulum, Jakarta: Ciputat Pers, 2002.

Purwanto, Ngalim, Psikologi Pendidikan, Bandung: Remaja Rosdakarya, 2000.

Pusat Bahasa Depdiknas, Kamus Besar Bahasa Indonesia, Jakarta: Balai Pustaka, 2003.

Slamet, Belajar dan Faktor-faktor Yang Mempengaruhi, Jakarta : Rineka Cipta, 1995, Edisi Revisi.

Soenarjo, dkk., Al-Qur'an dan Terjemahnya, Jakarta: Departemen Agama RI, 1989.

Sudjana, Nana, Dasar-dasar Proses Belajar Mengajar, Bandung : PT Sinar Baru Algensindo, 2000.

Surapranata, Sumarna dan Muhammad Hatta, Penilaian Portofolio, Bandung : PT Remaja Rosdakarya, 2004.

Surya, Moh., Psikologi Pembelajaran dan Pengajaran, Bandung: Pustaka Bani Qurays, 2004.

Syah, Muhibin, Psikologi Pendidikan dengan Pendekatan Baru, Bandung : Remaja Rosda Karya, 2000.

Thaha, Chabib dan Abdul Mu'ti, PBM PAI di Sekolah, Yogyakarta: Pustaka Pelajar, 1998.

Thoha, Chabib (Ed), PBM di Sekolah, Yogyakarta : Pustaka Pelajar, 1998. Tohirin, Psikologi Pembelajaran Pendidikan Agama Islam, Jakarta : PT Raja

Grafindo Persada, 2005.

Undang-undang Guru dan Dosen Undangundang No. 14, 2005, Semarang : CV. Duta Husiondo, 2006. 
Undang-Undang No. 2 Th. 2003 Tentang Sistem Pendidikan Nasional Sisdiknas dan Penjelasan, Yogyakarta : Media Wawancara Press, 2003.

Wiraatmaja, Metode Penelitian Tindakan Kelas, Bandung: Remaja Rosdakarya, 2005.

Witting, Arno F., Psychology of Learning, United States of America 